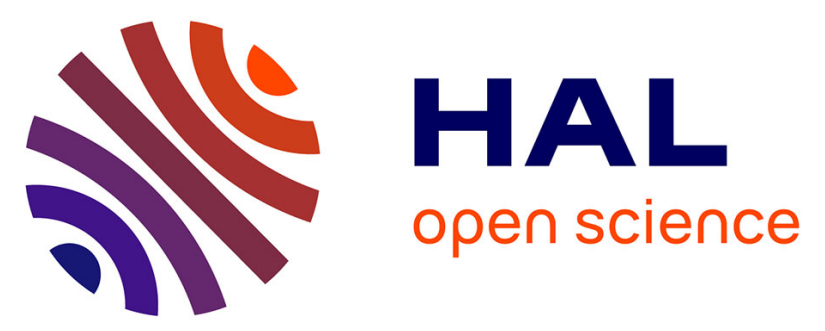

\title{
Sensitive Detection of Organophosphorus Pesticides Using a Needle Type Amperometric Acetylcholinesterase-based Bioelectrode. Thiocholine Electrochemistry and Immobilised Enzyme Inhibition
}

Graziella L. Turdean, Ionel Catalin Popescu, Liviu Oniciu, Daniel R. Thevenot

\section{- To cite this version:}

Graziella L. Turdean, Ionel Catalin Popescu, Liviu Oniciu, Daniel R. Thevenot. Sensitive Detection of Organophosphorus Pesticides Using a Needle Type Amperometric Acetylcholinesterase-based Bioelectrode. Thiocholine Electrochemistry and Immobilised Enzyme Inhibition. Journal of Enzyme Inhibition and Medicinal Chemistry, 2002, 17 (2), pp.107 - 115. hal-01180057

\author{
HAL Id: hal-01180057 \\ https://hal.science/hal-01180057
}

Submitted on 24 Jul 2015

HAL is a multi-disciplinary open access archive for the deposit and dissemination of scientific research documents, whether they are published or not. The documents may come from teaching and research institutions in France or abroad, or from public or private research centers.
L'archive ouverte pluridisciplinaire HAL, est destinée au dépôt et à la diffusion de documents scientifiques de niveau recherche, publiés ou non, émanant des établissements d'enseignement et de recherche français ou étrangers, des laboratoires publics ou privés. 


\title{
Sensitive Detection of Organophosphorus Pesticides Using a Needle Type Amperometric Acetylcholinesterase-based Bioelectrode. Thiocholine Electrochemistry and Immobilised Enzyme Inhibition
}

\author{
GRAZIELLA L. TURDEAN ${ }^{\mathrm{a}, *}$, IONEL CATALIN POPESCU ${ }^{\mathrm{a}}$, LIVIU ONICIU $^{\mathrm{a}}+$ and DANIEL R. THEVENOT ${ }^{\mathrm{b}}$ \\ a Department of Physical Chemistry, "Babes-Bolyai" University, 3400 Cluj-Napoca, Romania; ' Cereve (UMR 99 022 101), Faculté de Sciences et \\ Technologie, Université Paris XII-Val de Marne, 61 Avenue du Général de Gaulle, 94010 Créteil Cedex, France
}

(Received 21 November 2001)

An acetylcholinesterase (AChE) based amperometric bioelectrode for a selective detection of low concentrations of organophosphorus pesticides has been developed. The amperometric needle type bioelectrode consists of a bare cavity in a PTFE isolated Pt-Ir wire, where the AChE was entrapped into a photopolymerised polymer of polyvinyl alcohol bearing styrylpyridinium groups (PVA-SbQ). Cyclic voltammetry, performed at $\mathrm{Pt}$ and $\mathrm{AChE} / \mathrm{Pt}$ disk electrodes, confirmed the irreversible, monoelectronic thiocholine oxidation process and showed that a working potential of $+0.410 \mathrm{~V}$ vs. $\mathrm{Ag} / \mathrm{AgCl}, \mathrm{KCl}_{\text {sat }}$ was suitable for a selective and sensitive amperometric detection of thiocholine. The acetylthiocholine detection under enzyme kinetic control was found in the range of $0.01-0.3 \mathrm{U} \mathrm{cm}^{-2}$ of immobilised AChE. The detection limit, calculated for an inhibition ratio of $10 \%$, was found to reach $5 \mu \mathrm{M}$ for dipterex and $0.4 \mu \mathrm{M}$ for paraoxon. A kinetic analysis of the AChEpesticide interaction process using Hanes-Woolf or Lineweaver-Burk linearisations and secondary plots allowed identification of the immobilised enzyme inhibition process as a mixed one (non/uncompetitive) for both dipterex and paraoxon. The deviation from classical Michaelis Menten kinetics induced from the studied pesticides was evaluated using Hill plots.

Keywords: Acetylcholinesterase; Bioelectrode; Organophosphorus pesticides; Thiocholine

\section{INTRODUCTION}

Organophosphorus (OP) pesticides are widely used in agriculture as insecticides due to their high activity, low bioaccumulation and moderately rapid degradation in the environment. Nevertheless, a certain amount of the pesticides used is transferred in the surface runoff and subsurface drainage from agricultural land and can cause a spectrum of toxic effects on aquatic organisms and human beings. At the mammalian level, organophosphorus pesticides represent a serious risk because of their irreversible binding to the active site of acetylcholinesterase (AChE). This leads to hindered hydrolysis of the neurotransmitter-acetylcholine (ACh) resulting in the dysfunction of the transmission of nerve impulses with poisoning effects and nervous diseases. ${ }^{1-6}$ The measurements of OP compounds is classically done using chromatographic techniques. Because the traditional method is time consuming, the use of biosensors is an advantageous alternative. In the last decade, many authors have used free or immobilised AChE to detect organophosphorus pesticides. Thus, bioelectrodes based on potentiometric, ${ }^{7,8}$ amperometric $^{2-5,9-16}$ or optical ${ }^{17-19}$ detection methods have been recently developed.

When a thiocholine ester is used as substrate, monoenzymatic detection based on the following sequence of reactions, catalysed by $\mathrm{AChE}$ is necessary:

$$
\underset{\text { (acetylthiocholine) }}{\left(\mathrm{CH}_{3}\right)_{3} \mathrm{~N}^{+}}\left(\mathrm{CH}_{2}\right)_{2}-\mathrm{S}-\mathrm{CO}-\mathrm{CH}_{3}+\mathrm{H}_{2} \mathrm{O} \stackrel{\mathrm{AChE}}{\longrightarrow} \underset{\text { (thiocholine) }}{\left(\mathrm{CH}_{3}\right)_{3} \mathrm{~N}^{+}-\left(\mathrm{CH}_{2}\right)_{2}-\mathrm{SH}+\mathrm{CH}_{3} \mathrm{COOH}}
$$

$$
2\left(\mathrm{CH}_{3}\right)_{3} \mathrm{~N}^{+}-\left(\mathrm{CH}_{2}\right)_{2}-\mathrm{SH} \underset{\text { oxidation }}{\stackrel{\text { anodic }}{\longrightarrow}} \begin{aligned}
& \left.\right|_{\text {(thiocholine) }} \\
& \left.\mathrm{S}-\left(\mathrm{CH}_{2}\right)_{2}-\mathrm{N}^{+}\left(\mathrm{CH}_{3}\right)_{3}\right)^{-} \mathrm{N} \\
& \text { (disulfide compound) }
\end{aligned}
$$

*Corresponding author. E-mail: gturdean@chem.ubbcluj.ro

+Passed away. 
Because the electrochemical oxidation of the thiol compounds at solid electrodes occurs at relatively high potentials, ${ }^{20}$ an alternative detection system based on the thiocholine biochemical oxidation in the presence of choline oxidase $(\mathrm{ChO})$, and followed by the hydrogen peroxide direct ${ }^{21-23}$ or mediated ${ }^{24}$ quantification was proposed. However, it should be noted that, due to their inherent simplicity, the monoenzyme systems ${ }^{3-5,7-8,10-16,25-28}$ are much easier to control than the bi- (i.e. AChE + $\mathrm{ChO})^{21-23,29-30}$ or trienzyme (i.e. $\mathrm{AChE}+\mathrm{ChO}+$ horseradish peroxidase $)^{24}$ ones.

The aims of the work were, firstly, to investigate the electrochemical behaviour of the oxidation of thiocholine at platinum electrode (Eq. (2)), using both cyclic and hydrodynamic voltammetry, in order to establish the optimal applied potential for the transduction step. Secondly, taking advantage of a simple, inexpensive and enzyme activity preserving immobilisation technique ${ }^{5,31}$ an AChE based bioelectrode using the needle type model was constructed, optimised and used for dipterex (triclorfon) and paraoxon detection. Finally, a kinetic analysis of the inhibition data was used to identify the mechanism of the immobilised enzyme inhibition, as well as to estimate the kinetic parameters of the pesticide biorecognition process.

\section{EXPERIMENTAL}

\section{Chemicals}

Acetylcholinesterase (AChE) (E.C. 3.1.1.7, type V-S, from Electric eel, $970 \mathrm{U} / \mathrm{mg}$ solid), used as such without any purification treatment, and acetylthiocholine chloride $(\mathrm{ASChCl})$, used as substrate, were purchased from Sigma. Polyvinylalcohol bearing styrylpyridinium groups (PVA-SbQ) (degree of polymerisation 1700 , degree of saponification 88, SbQ content $1.3 \mathrm{~mol} \%$, and solid content $11 \%$, pH 7) was obtained from Toyo Gosei Kogyo, Ltd., Japan. Paraoxon ethyl $\left(\mathrm{C}_{10} \mathrm{H}_{15} \mathrm{NO}_{6} \mathrm{P}\right)$ was purchased from CIL-Cluzeau, France. Dipterex (trichlorfon) $\left(\mathrm{C}_{4} \mathrm{H}_{8} \mathrm{Cl}_{3} \mathrm{O}_{4} \mathrm{P}\right)$ was a kind gift from "R. Ripan" Institute of Chemistry, Cluj-Napoca, Romania. All other chemicals were of analytical grade (Merck, Prolabo and Reactivul-Bucarest) and were used without any further purification.

A solution of $50 \mathrm{mM}$ of thiocholine (SCh) was prepared by enzymatic reaction between appropriate amounts of $\mathrm{ASChCl}$ and $\mathrm{AChE}$ in $1 / 15 \mathrm{M}$ phosphate buffer, $\mathrm{pH}$ 8. The enzymatic reaction was allowed to proceed for $1.5 \mathrm{~h}$ at $37^{\circ} \mathrm{C}$ and $\mathrm{pH} 8$. The $50 \mathrm{mM}$ $\mathrm{ASChCl}$ solutions were freshly prepared just before use, by dissolving the appropriate amount of salt in phosphate buffer. The supporting electrolyte was a $1 / 15 \mathrm{M}$ phosphate buffer ( $\mathrm{pH} 8$ ) prepared by mixing the necessary amounts of $\mathrm{Na}_{2} \mathrm{HPO}_{4} \cdot 12 \mathrm{H}_{2} \mathrm{O}$ and $\mathrm{KH}_{2} \mathrm{PO}_{4}$, in the presence of $0.03 \mathrm{M} \mathrm{NaCl}, 0.0026 \mathrm{M}$ $\mathrm{KCl}$ and $0.002 \mathrm{M} \mathrm{MgCl}{ }_{2}{ }^{4,5,32}$ The same buffer solution was used also for the preparation of the enzyme, substrate and pesticide solutions. All solutions were prepared with distilled water.

\section{Bioelectrode (AChE/Pt) Design}

The schematic diagram of the needle type $\mathrm{AChE}$ based amperometric bioelectrode $(\mathrm{AChE} / \mathrm{Pt})$ is shown in Fig. 1.

The electrode was a Pt-Ir (10\% Ir) wire (Medwire, Phymep, France) with a diameter of $0.170 \mathrm{~mm}$, coated with a PTFE film $(0.250 \mathrm{~mm}$ outer diameter $){ }^{33,34}$ At the tip of the wire, a cavity was made in the PTFE coating, where $2 \mu \mathrm{l}$ was deposited from a mixture containing $100 \mu \mathrm{l}$ aqueous solution of AChE $\left(410 \mathrm{U} \mathrm{ml}^{-1}\right)$ and $0.1 \mathrm{~g}$ of photocrosslinkable polymer, PVA-SbQ. The enzyme was physically entrapped without formation of any covalent binding, ${ }^{5,31}$ by polymerisation of PVA-SbQ by exposure to the light of an electric bulb for $2 \mathrm{~h}$ at $4^{\circ} \mathrm{C}$, followed by a dark storage of $2 \mathrm{~h}$ at $20^{\circ} \mathrm{C}$. ${ }^{4}$ After preparation, the bioelectrode was stored at $4^{\circ} \mathrm{C}$.

\section{Electrochemical Measurements}

For studying thiocholine oxidation, both cyclic and hydrodynamic voltammetry methods were used. Only in this case the working electrode was the platinum disk electrode ( $2 \mathrm{~mm}$ diameter). Cyclic voltammetry was performed with a polarographic analyser (Model 384B, EG and G Princeton Applied Research) coupled with an X-Y recorder. The working electrode was either an unmodified Pt disk electrode

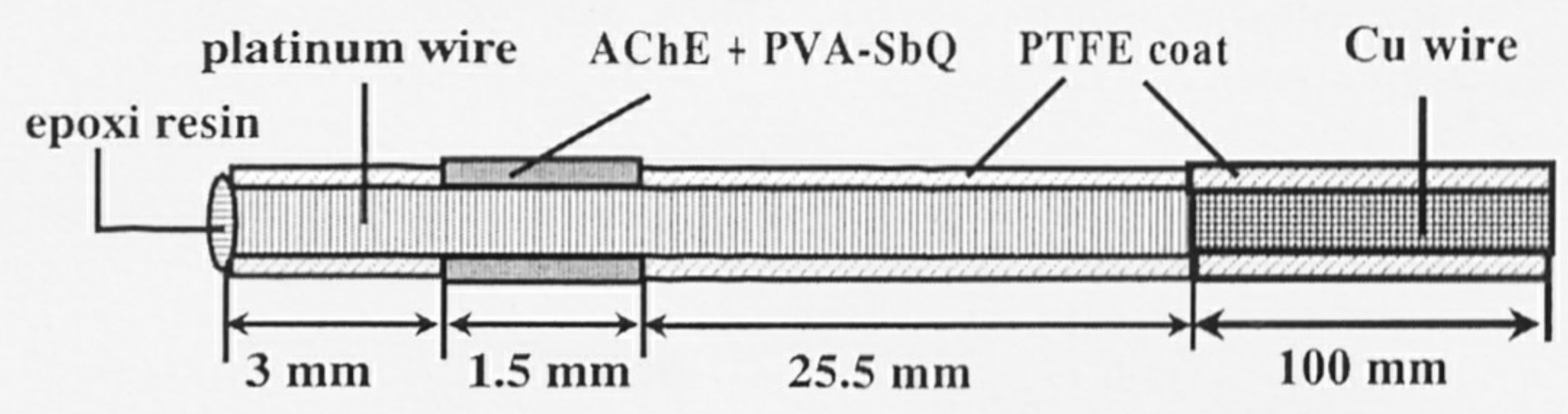

FIGURE 1 Schematic diagram of the needle type acetylcholinesterase based bioelectrode (AChE/Pt). 
$(\mathrm{Pt})$ or the same electrode modified by an enzyme matrix incorporating $49.6 \%(\mathrm{w} / \mathrm{w})$ AChE in PVA$\mathrm{SbQ}$ (AChE/Pt). Before use, the bare Pt electrode was polished with emery paper (BAO3, RadiometerCopenhagen, France) and then thoroughly rinsed with distilled water. The working potential was scanned between -0.2 and $+1.2 \mathrm{~V}$ vs. $\mathrm{Ag} / \mathrm{AgCl}$, $\mathrm{KCl}_{\text {sat }}$.

The hydrodynamic voltammetric work at an unmodified platinum disk electrode was done using a modulated speed rotator (model AMSFRX, Pine, Grove City, SUA). The corresponding electrochemical data were collected with a computer controlled electrochemical system consisting of a low current potentiostat (Polarograph LP7e, Czech Republic), a data acquisition card (AT MOI-16F, National Instruments, USA) and a PC-486 (Olivetti, Switzerland). Custom-made software based on LabView 3.1 monitored the potentiostat functions. ${ }^{35}$

In all voltammetric investigations a conventional three-electrode cell equipped with an $\mathrm{Ag} / \mathrm{AgCl}$, $\mathrm{KCl}_{\text {sat. }}$ (Radiometer, France) (for cyclic voltammetry) or with a saturated calomel electrode ("R. Ripan" Institute of Chemistry, Cluj-Napoca, Romania) (for hydrodynamic voltammetry) was used as reference electrode and a platinum wire as auxiliary electrode. The investigated solution was degassed for $15 \mathrm{~min}$ by argon bubbling. The reference and auxiliary electrodes were separated from the sample solution by a Luggin's capillary, filled with a $\mathrm{KCl}$ saturated solution. All measurements were carried out at ambient temperature, i.e. about $20 \pm 0.5^{\circ} \mathrm{C}$.

Batch amperometric measurements with the needle type AChE based bioelectrode were carried out using the same undivided thermostated threeelectrode cell. The desired constant potential difference between the working and the reference electrode $\left(\mathrm{Ag} / \mathrm{AgCl}, \mathrm{KCl}_{\text {sat }}\right)$ was applied using a potentiostat (PRG-DEL, Tacussel, France or Metrohm 641 VA-Detector, Switzerland). The resulting current was displayed on an X-t recorder (Linseis L6514,
France or $W+W$ Recorder, Switzerland). The solution stirred at a constant rate was maintained at $30 \pm 0.5^{\circ} \mathrm{C}$.

\section{RESULTS AND DISCUSSIONS}

\section{Electrochemical Behaviour of Thiocholine}

In view to investigate the oxidation of thiocholine, its voltammetric response was recorded at $\mathrm{Pt}$ and AChE/Pt electrodes at different $(10-100 \mathrm{mV} / \mathrm{s})$ potential scan rates (Fig. 2B).

Irrespective of the electrode modification, the potential peak splitting and the shape of the voltammetric wave indicated a pronounced irreversibility of the thiocholine redox process (Fig. 2A and 2B). The linear dependence between the anodic peak current $I_{\mathrm{p}, \mathrm{a}}$ and the square root of potential scan rate (Fig. 2C) proves that the thiocholine oxidation rate is controlled by diffusion.

Based on this assumption and using the equation describing the dependence of the peak current $\left(I_{\mathrm{p}, \mathrm{a}} / \mathrm{A}\right)$ on the potential scan rate $\left(\mathrm{v} / \mathrm{V} \mathrm{s}^{-1}\right)$ for an irreversible process (Eq. (3)) and the equation giving the difference between the anodic peak potential $\left(E_{\mathrm{p}, \mathrm{a}}\right)$ and the potential for half peak current $\left(E_{\mathrm{p} / 2}\right)$ (Eq. (4)), the thiocholine diffusion coefficient was determined. ${ }^{36,37}$

$$
\begin{gathered}
I_{\mathrm{p}, \mathrm{a}}=2.99 \times 10^{-5} n\left(\alpha n_{\mathrm{a}}\right)^{1 / 2} A[S C h] D_{\mathrm{SChE}}^{1 / 2} v^{1 / 2} \\
E_{\mathrm{p}, \mathrm{a}}-E_{\mathrm{p} / 2}=47.7 /\left(\alpha n_{\mathrm{a}}\right)
\end{gathered}
$$

where: $n$ is the total number of electrons, $\alpha$ the transfer coefficient, $n_{\mathrm{a}}$ the number of electrons transferred in the rate determining step, $A$ the electrode surface $\left(\mathrm{cm}^{2}\right)$, [SCh] the thiocholine concentration $\left(\mathrm{mol} \mathrm{cm}^{-3}\right)$, and $D_{\mathrm{SChE}}$ the thiocholine diffusion coefficient $\left(\mathrm{cm}^{2} \mathrm{~s}^{-1}\right)$.

Thus, the analysis of anodic waves, recorded by cyclic voltammetry measurements at $50 \mathrm{mV} \mathrm{s}^{-1}$, gave an average value for the $\alpha n_{\text {a }}$ products of 0.33 and 0.22 for $\mathrm{Pt}$ and $\mathrm{AChE} / \mathrm{Pt}$ electrodes, respectively. Taking

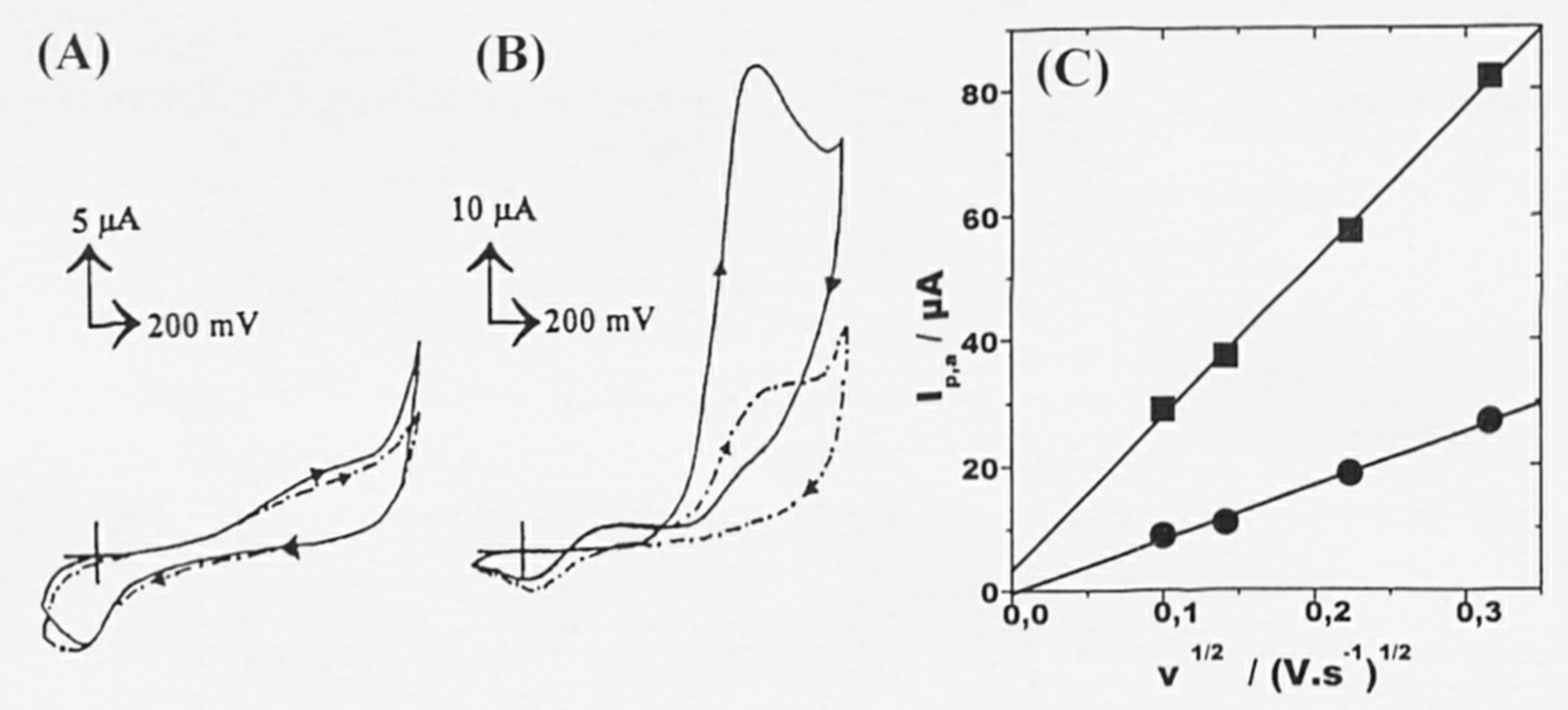

FIGURE 2 Voltammetric response at $\mathrm{Pt}(-)$ and $\mathrm{AChE} / \mathrm{Pt}(---)$ electrodes in phosphate buffer $(\mathrm{A})$ and in the presence of thiocholine (B). Dependence of the anodic peak current $\left(I_{p, a}\right)$ on the potential scan rate for Pt $(\square)$ and AChE/Pt $(\bullet)$ electrodes $(\mathrm{C})$. Experimental conditions: $1 / 15 \mathrm{M}$ phosphate buffer $(\mathrm{pH} 8) ; 0.0166 \mathrm{M}$ thiocholine in buffer solution; starting potential, $-0.2 \mathrm{~V} v \mathrm{~s} . \mathrm{Ag} / \mathrm{AgCl}, \mathrm{KCl}$ sat.; $\mathrm{scan}$ rate, $50 \mathrm{mV} \mathrm{s}^{-1}$; deaerated solution; room temperature. 

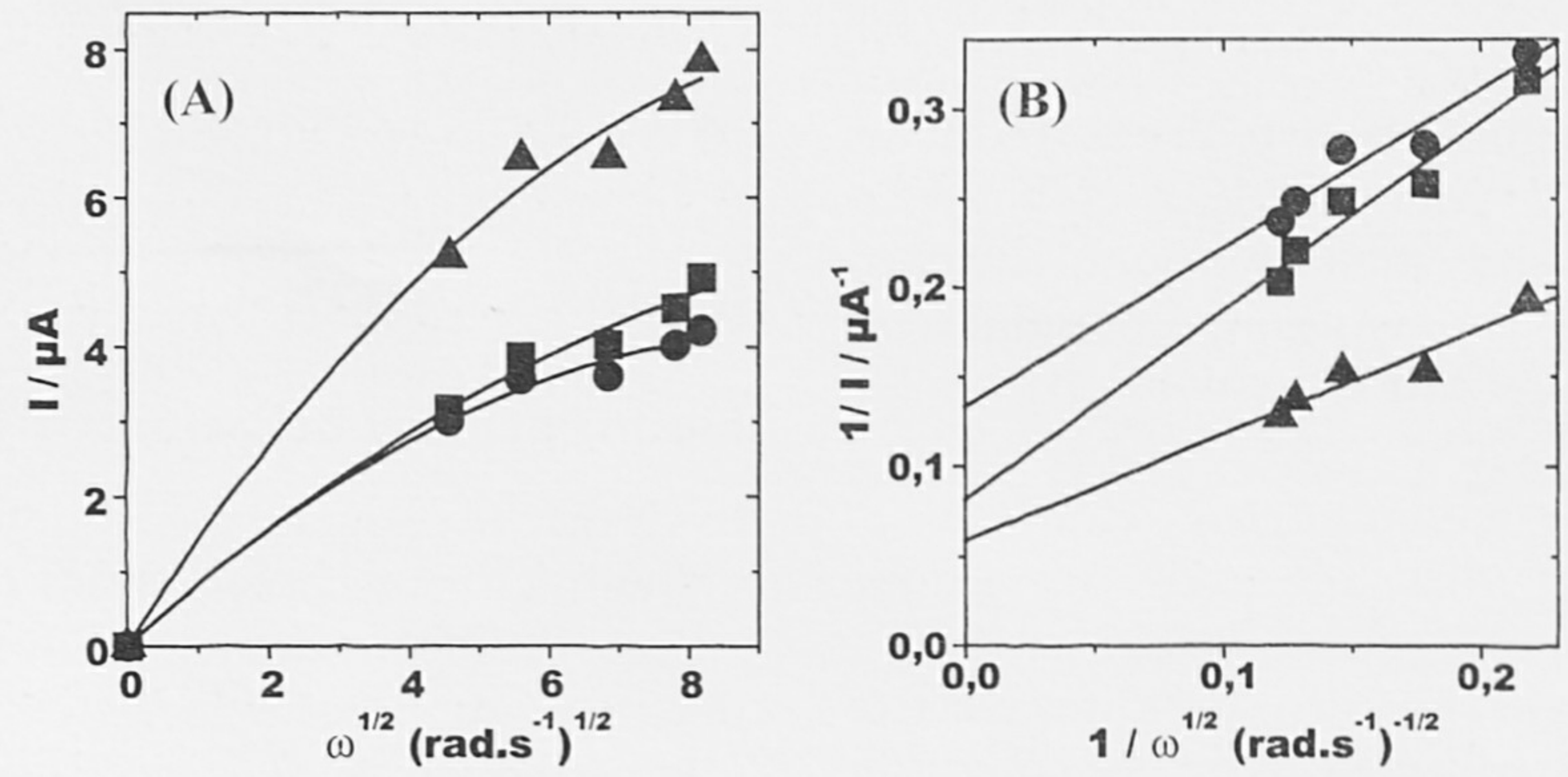

FIGURE 3 Levich (A) and Koutecky-Levich (B) plots for the steady state thiocholine oxidation at Pt rotating disk electrode: $0.250 \mathrm{~V} v$.

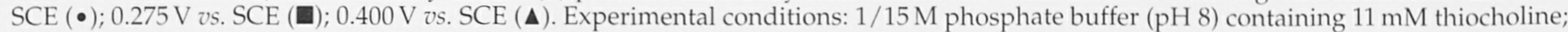
deaerated solution; room temperature.

into account that the thiocholine oxidation is a oneelectron process, ${ }^{38,39}$ the calculated values for $\alpha$, within experimental error, were found to be slightly dependent on the electrode surface conditions. Moreover, in both cases they were significantly lower than 0.5 , suggesting a noteworthy difference between the redox behaviour of thiocholine and its oxidised form, probably due to the stronger adsorption of a disulphur compound at the bare $\mathrm{Pt}$ electrode. Using the above mentioned values for $\alpha n_{\mathrm{a}}$ products, the diffusion coefficient for thiocholine was found higher at bare $\mathrm{Pt}$ electrode, $(8 \pm 0.1) \times 10^{-6} \mathrm{~cm}^{2} \mathrm{~s}^{-1}$, than at AChE/Pt electrode, $(2 \pm 0.1) \times 10^{-6} \mathrm{~cm}^{2} \mathrm{~s}^{-1}$, proving a hindered mass transport across the enzyme-containing polymer matrix.

On the other hand, the cyclic voltammetry experiments showed that for both investigated electrode configurations, a diffusion-controlled current could be obtained for values of the applied potential higher than $+0.8 \mathrm{~V}$ vs. $\mathrm{Ag} / \mathrm{AgCl}, \mathrm{KCl}_{\text {sat }}$. Nevertheless, it was reported ${ }^{40-42}$ that an applied potential of ca. $+0.4 \mathrm{~V}$ vs. Ag/ $\mathrm{AgCl}, \mathrm{KCl}_{\text {sat }}$ is still convenient for a selective and sensitive amperometric detection of SCh. This unusual width of the applied potential window exploited for amperometric detection is the result of the marked irreversibility of thiocholine electrochemical oxidation.

In order to obtain more information about the thiocholine electrochemical oxidation at an unmodified $\mathrm{Pt}$ electrode, hydrodynamic voltammetry measurements were conducted using a rotating disk electrode (RDE).

The nonlinear dependence of the thiocholine oxidation current $(I)$ on the square root of the rotating speed $(\omega)$ showed an incomplete developed region of diffusion-kinetic mixed control (Levich plot, Fig. 3A). Using the Koutecky-Levich plot $^{43}$ (Eq. (5)), the thiocholine diffusion coefficient $D_{\text {SCh }}$ was estimated from the slope, while the electrochemical rate constant of the heterogeneous electron transfer was calculated from the intercept (Fig. 3B).

$$
\begin{aligned}
(1+I)= & \left(1 / I_{\mathrm{k}}\right)+(1.61 \\
& \left.\times D_{\mathrm{SCh}}^{-2 / 3} \nu^{1 / 6} \omega^{-1 / 2}\right) /(n F A[\mathrm{SCh}])
\end{aligned}
$$

where $I_{\mathrm{k}}$ is the kinetic current.

The thiocholine diffusion coefficient, $D_{\mathrm{SCh}}$, obtained from RDE measurements $(2.3 \times$ $10^{-7} \mathrm{~cm}^{2} \mathrm{~s}^{-1}$, potential range was between +0.25 and $+0.4 \mathrm{~V}$ vs. SCE) was much lower than the corresponding value found from cyclic voltammetry measurements $\left(8 \times 10^{-6} \mathrm{~cm}^{2} \mathrm{~s}^{-1}\right.$, potentials higher than $+0.825 \mathrm{~V}$ vs. $\left.\mathrm{Ag} / \mathrm{AgCl}, \mathrm{KCl}_{\text {sat }}\right)$. Such a large difference could be due to a still obscure dependence of the thiocholine oxidation process on adsorption reactions related to the value of applied potential. The electrochemical rate constant of the heterogeneous electron transfer was slightly affected by the electrode potential, varying from $2.2 \times 10^{-4}$ to $5.1 \times 10^{-4} \mathrm{~cm} \mathrm{~s}^{-1}$ in the $0.25-0.4 \mathrm{~V}$ vs. $\mathrm{Ag} / \mathrm{AgCl}$, $\mathrm{KCl}_{\text {sat }}$ applied potential range. Unfortunately, the absence of a reliable value for the standard potential of thiocholine redox couple, made impossible the determination of the standard rate constant for the heterogeneous electron transfer in the thiocholine oxidation at $\mathrm{pH} 8.0$.

\section{Enzyme Loading Optimisation}

In order to establish the AChE optimal loading for the bioelectrode construction, calibration curves for acetylthiocholine (from 0.1 to $4.5 \mathrm{mM}$ ) were recorded in batch amperometric experiments for needle type bioelectrodes incorporating various amounts of immobilised enzyme. Two values of the applied potential were chosen: one was obtained from cyclic voltammetry measurements (i.e. $+0.825 \mathrm{~V}$ vs. $\left.\mathrm{Ag} / \mathrm{AgCl}, \mathrm{KCl}_{\text {sat }}\right)$ and the other one was already used in the literature ${ }^{4-5}$ for the amperometric detection of thiocholine (i.e. $+0.410 \mathrm{~V}$ vs. $\mathrm{Ag} / \mathrm{AgCl}$, $\left.\mathrm{KCl}_{\text {sat }}\right)$. 
TABLE I Kinetic parameters for needle type bioelectrodes, with different AChE loading, calculated from the Lineweaver-Burk linearisation of the amperometric calibration curves for $\mathrm{ASChCl}$, at two applied potentials. Experimental conditions: phosphate buffer $1 / 15 \mathrm{M}, \mathrm{pH} 8$; temperature $30^{\circ} \mathrm{C}$; stirred solution, average for 3 electrodes tested

\begin{tabular}{|c|c|c|c|c|}
\hline \multirow{3}{*}{$\begin{array}{l}\text { AchE loading } \\
\left(\mathrm{U} / \mathrm{cm}^{2}\right)\end{array}$} & \multicolumn{4}{|c|}{$\begin{array}{c}\text { Applied potential } \\
\left(\mathrm{V} \text { vs. } \mathrm{Ag} / \mathrm{AgCl}, \mathrm{KCl}_{\text {sat }}\right)\end{array}$} \\
\hline & \multicolumn{2}{|c|}{+0.410} & \multicolumn{2}{|c|}{+0.825} \\
\hline & $\begin{array}{l}\mathrm{K}_{\mathrm{M}}^{\mathrm{app}} \\
(\mathrm{mM})\end{array}$ & $\begin{array}{l}I_{\max } \\
(\mathrm{nA})\end{array}$ & $\begin{array}{l}\mathrm{K}_{\mathrm{M} p}^{\mathrm{app}} \\
(\mathrm{mM})\end{array}$ & $\begin{array}{l}I_{\max } \\
(\mathrm{nA})\end{array}$ \\
\hline 0.012 & $6.5 \pm 0.5$ & $33 \pm 2$ & $9.3 \pm 3.2$ & $145 \pm 43$ \\
\hline 0.06 & $3.4 \pm 0.2$ & $31 \pm 1$ & $4.4 \pm 1.2$ & $114 \pm 23$ \\
\hline 0.12 & $1.4 \pm 0.3$ & $34 \pm 4$ & $1.8 \pm 0.5$ & $122 \pm 19$ \\
\hline 0.28 & $1.4 \pm 0.2$ & $41 \pm 3$ & $3.7 \pm 1.2$ & $221 \pm 52$ \\
\hline 3.0 & $2.5 \pm 0.2$ & $400 \pm 24$ & $6.8 \pm 0.3$ & $1493 \pm 48$ \\
\hline 9.0 & $5.3 \pm 0.4$ & $600 \pm 40$ & - & - \\
\hline 15.2 & $7.8 \pm 1.0$ & $780 \pm 93$ & $9.8 \pm 2.7$ & $1587 \pm 381$ \\
\hline
\end{tabular}

$K_{\mathrm{M}}^{\mathrm{app}}$ and $I_{\max }$ confidence intervals were estimated as $S_{A / B} \times t_{N-2 ; 0.95}$ and $S_{1 / B} \times t_{N-2 ; 0.95}$; respectively; $S_{A / B}$ is the standard deviation of the ratio $A / B$; $S_{1 / B}$ is the standard deviation of $1 / B ; A$ and $B$ are the Lineweaver-Burk linear regression parameters; $N$ is the number of experimental data; $t$ is the Student's variable corresponding to $(N-2)$ degrees of freedom and $95 \%$ probability.

In the enzyme kinetic controlled domain (low enzyme loading range), a 10 times increase of the enzyme loading (from 0.28 to $3 \mathrm{U} \mathrm{cm}^{-2}$ ) induced a proportional increase of the maximum intensity (for example, 9.75 times when the applied potential was $+0.410 \mathrm{~V})$, proving an efficient immobilization technique. However, enzyme loading higher than $3 \mathrm{U} \mathrm{cm}^{-2}$ was not required for ASCh detection performed at both investigated applied potentials. On the other hand, the increase of the bioelectrodes sensitivity with the increase of the applied potential value suggested that, at least for high enzyme loadings, the needle type bioelectrode response could be controlled by the electrochemical reaction rate. It is interesting to notice similar dependencies of the Michaelis-Menten parameters on the enzyme loading for both applied potential values (Table I). The $K_{\mathrm{M}}^{\mathrm{app}}$ variation trend might be due to an initial increase followed by a continuous decrease of the polymer matrix permeability, both induced by the increase of the enzyme loading. As expected, at higher amounts of immobilised enzyme the maximum current levelled off. ${ }^{44}$

The acetylthiocholine detection limit was slightly influenced by the bioelectrode enzyme loading and the applied potential. For example, a value of 21 and $28 \mu \mathrm{M}$ was found for a bioelectrode incorporating 0.12 and $3 \mathrm{U} \mathrm{cm}^{-2}$, respectively (the estimation was done for a signal to noise ratio equal to 3 ).

In spite of an important bioelectrode sensitivity loss (i.e. less than 50\%), an applied potential of $+0.410 \mathrm{~V}$ vs. $\mathrm{Ag} / \mathrm{AgCl}, \mathrm{KCl}_{\text {sat }}$ was selected for all further experiments in order to diminish the possible electrochemical interferences.

\section{AChE Inhibition by Organophosphorus Pesticides}

Preliminary experiments have shown that reproducible results regarding the pesticide detection sensitivity and bioelectrode stability were obtained for enzyme loading significantly higher than the value found for the diffusion controlled detection of thiocholine. This apparent enzyme overloading was necessary to compensate the biosensor deactivation due to the intrinsic instability of the enzyme, enhanced by the working temperature $\left(30^{\circ} \mathrm{C}\right)$.

In order to investigate the paraoxon and dipterex inhibition effect on the AChE activity, two types of experimental methods were used. The first one (method I) consisted in the recording of the bioelectrode amperometric response to successive additions of $\mathrm{ASChCl}$, before and after its incubation, for a given period of time, in the presence of a pesticide (Fig. 4A). Thus, the method allowed calculation of the percent of inhibition $(\Delta I /$ $\left.I_{0}, \%\right),{ }^{14,45}$ defined as the ratio between the decrease of the bioelectrode response $(\Delta I)$ induced by the given concentration of the inhibitor and the bioelectrode initial response $\left(I_{0}\right)$ when the inhibitor was absent.

The second one (method II) corresponded to recording the bioelectrode response to successive additions of pesticide in the presence of a given concentration of $\mathrm{ASChCl}$ (Fig. 4B). Taking into account that the rate of the signal decrease $(\mathrm{d} I / \mathrm{d} t)$ is proportional to the inhibitor concentration, it was stated that improved results could be obtained for the detection of slowly reacting inhibitors. ${ }^{13-16}$ From the experimental results provided by the second method, the relative rate of inhibition (RI) was calculated as the ratio between the maximum inhibition rate $(\mathrm{d} I / \mathrm{d} t)_{\max }$ and the initial response $\left(I_{0}\right)$.

In Fig. 5 is presented the experimentally observed dependence of the AChE percent of inhibition and the relative rate of inhibition on the paraoxon concentration. As expected, both types of curves show a sigmoid dependence on the pesticide concentration. The middle part of the curves exhibits a well-defined inhibition zone where, the relative errors are lower-this region could be considered the real "working calibration curve". ${ }^{46}$ The detection limit, defined as the pesticide concentration inducing a $10 \%$ inhibition, ${ }^{46,47}$ was found to be $5 \mu \mathrm{M}$ (1.32 ppm) for dipterex and $0.4 \mu \mathrm{M}(0.11 \mathrm{ppm})$ for paraoxon. Both values are larger than those reported in the literature ${ }^{8,48,49}$ (e.g. the lowest ${ }^{4}$ reported for paraoxon was $10^{-10} \mathrm{M}$ ), but the reasons for such difference are difficult to determine due to differences existing between the used transducer (amperometric/potentiometric), the construction (immobilization technique) and the experimental conditions (substrate nature, concentration range, applied potential). 
(A)

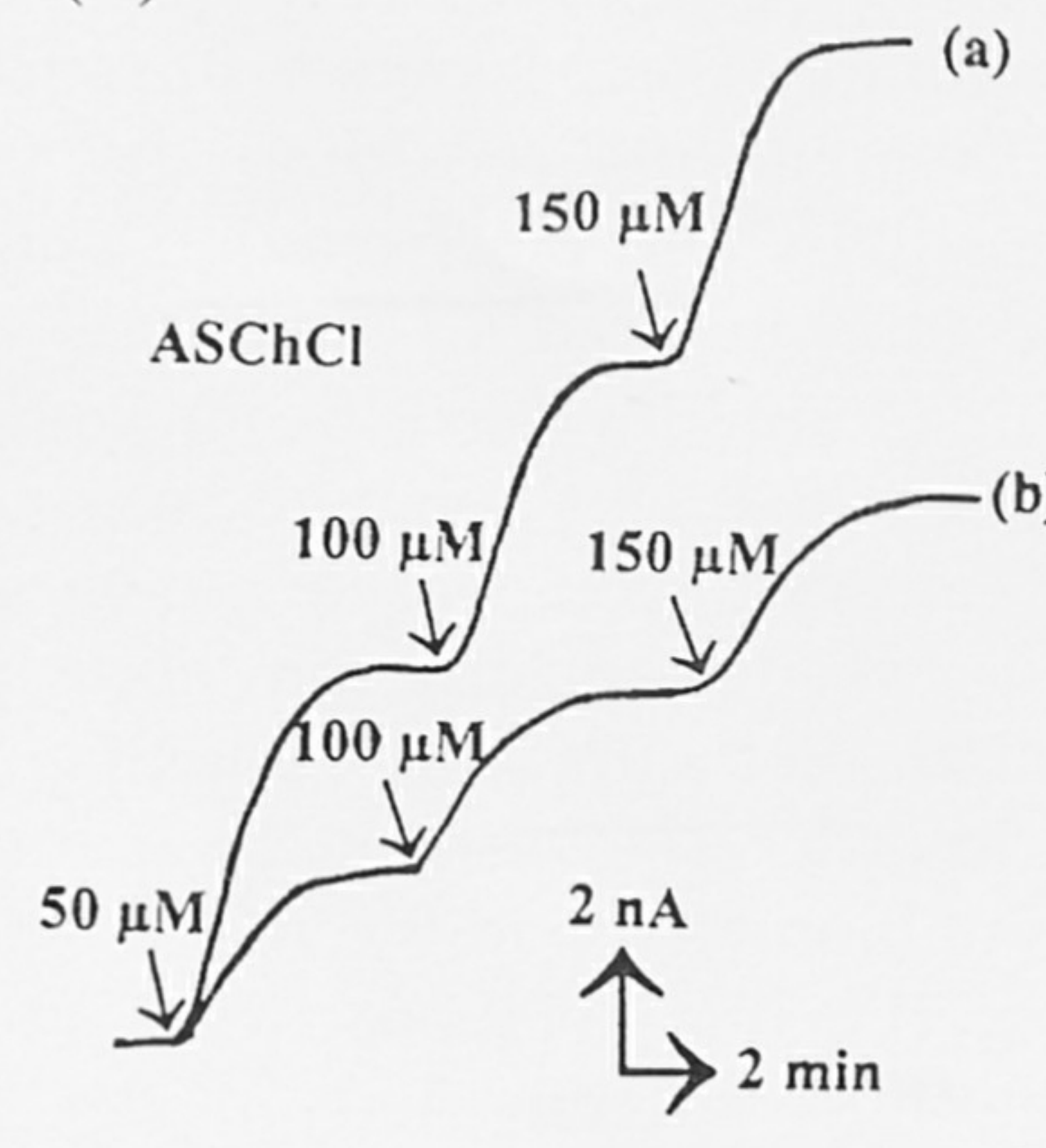

(B)

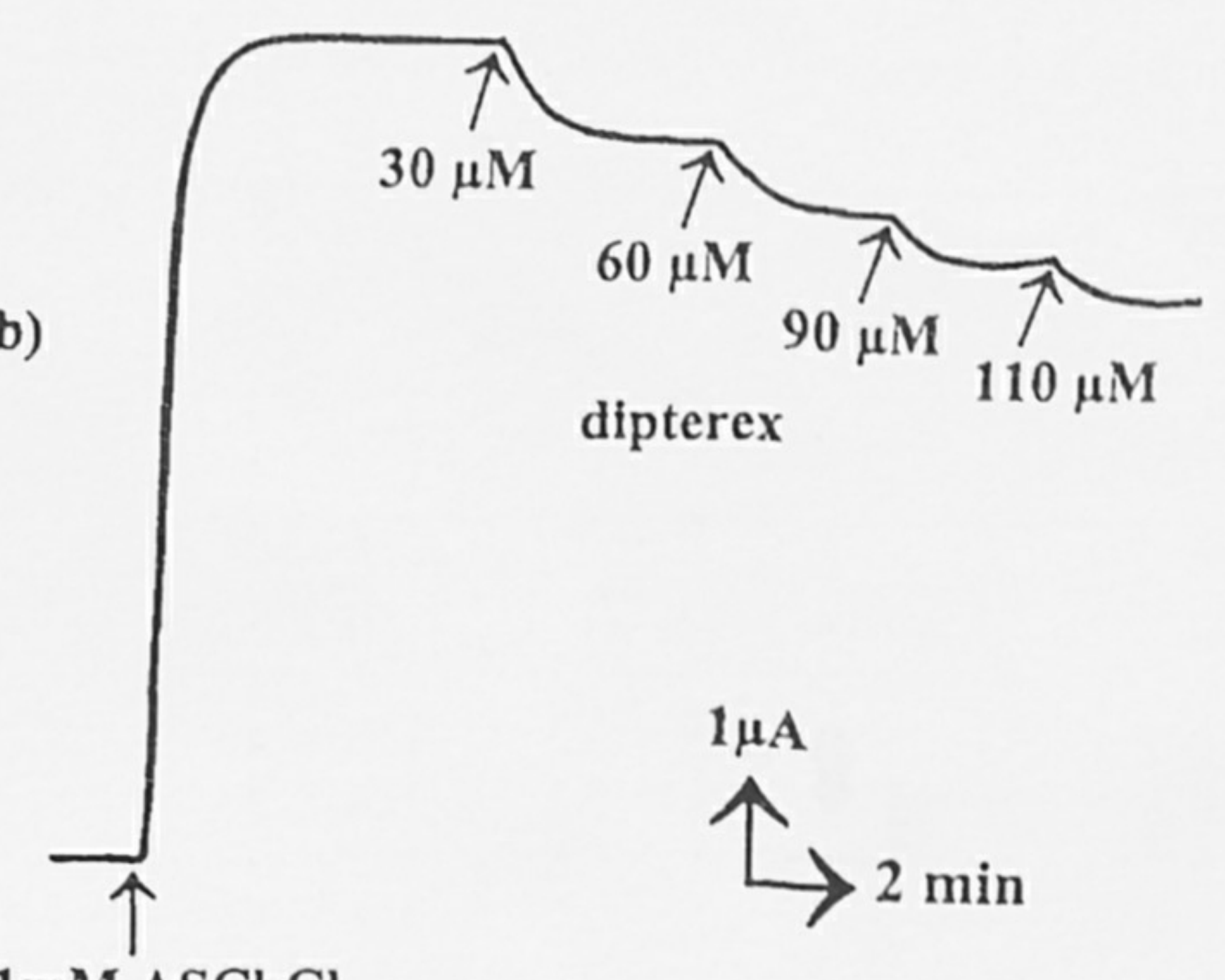

FIGURE 4 Steady state current response of an AChE based bioelectrode: (A) to successive increments of acetylthiocholine concentration in $50 \mu \mathrm{M}$ steps, before (a) and after (b) $30 \mathrm{~min}$ incubation in $0.4 \mathrm{mM}$ dipterex; (B) to successive additions of dipterex in $30 \mu \mathrm{M}$ steps, in the presence of $1 \mathrm{mM}$ acetylthiocholine. Experimental conditions: applied potential, $+0.410 \mathrm{~V} v s . \mathrm{Ag} / \mathrm{AgCl}, \mathrm{KCl}_{\text {sat; }}$ phosphate buffer $1 / 15 \mathrm{M}$, $\mathrm{pH} \mathrm{8}$; temperature $30^{\circ} \mathrm{C}$; stirred solution.

More information about the inhibition induced by the investigated organophosphorus pesticides on the immobilised AChE activity was obtained from the kinetic analysis of the needle type bioelectrodes response in the presence of paraoxon or dipterex. For this reason, bioelectrodes with the same enzyme loading and similar analytical characteristics were assessed by method I. As a typical example, the recorded calibration curves for acetylthiocholine, obtained in the presence of different paraoxon and dipterex concentrations are presented in the Fig. 6. Subsequently, for both inhibitors the apparent kinetic parameters $K_{\mathrm{M}}^{\text {app }}$ and $I_{\max }$ were calculated using the Hanes-Woolf linearisation (Fig. 6A,B and Table II).

In the presence of pesticides, the $I_{\max }$ variations are more important than those corresponding to $K_{\mathrm{M}}^{\mathrm{app}}$.

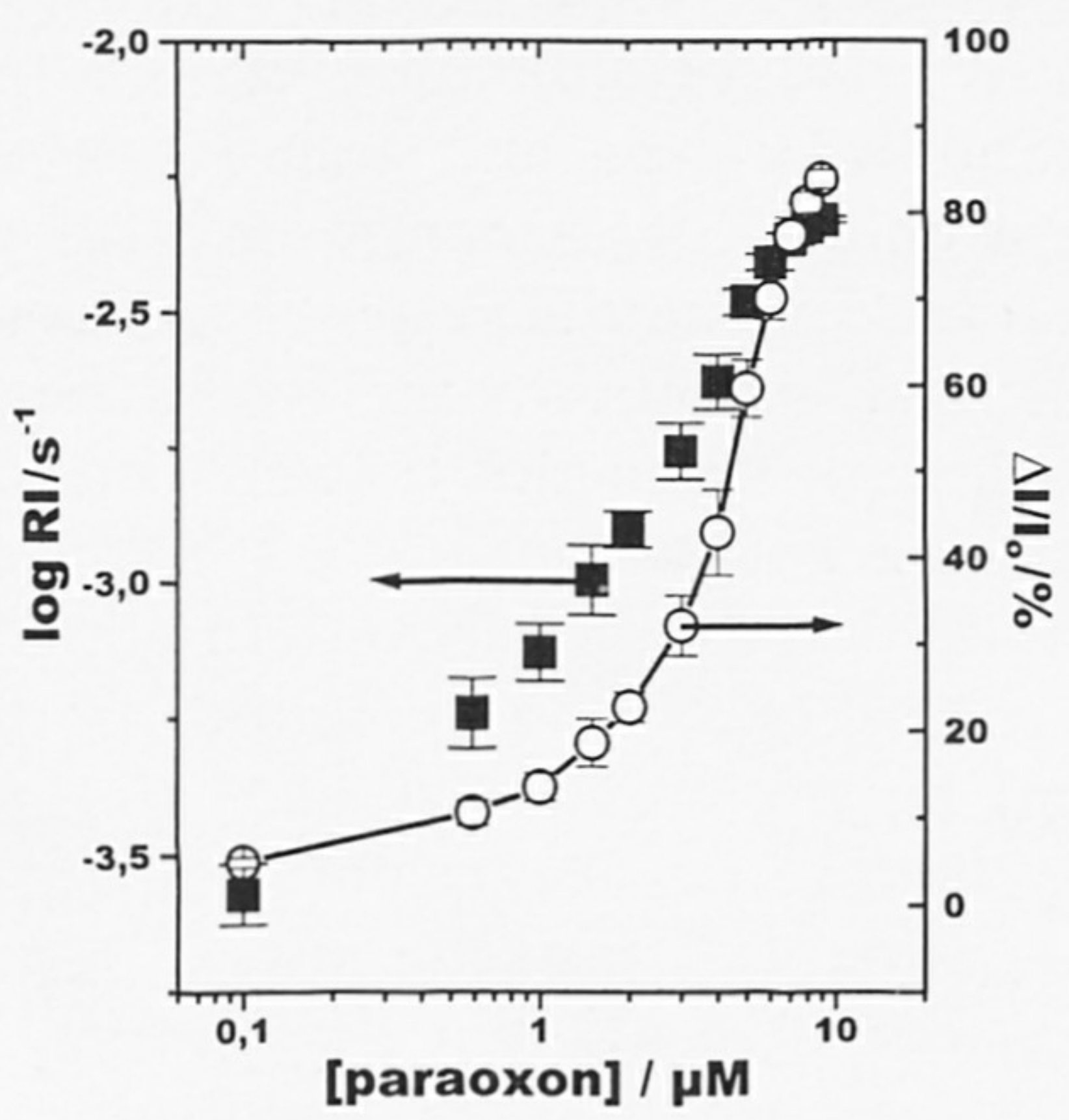

FIGURE 5 Dependence of the percent of inhibition $(O)$ and the relative rate of inhibition ( $\mathbf{\square})$ on the paraoxon concentration. Experimental conditions: method I (O), method II (ם); applied potential, $+0.410 \mathrm{~V} v$ s. $\mathrm{Ag} / \mathrm{AgCl}, \mathrm{KCl}_{\text {sat }} ; 1 / 15 \mathrm{M}$ phosphate buffer containing $200 \mu \mathrm{M} \mathrm{ASChCl}, \mathrm{pH} 8$; temperature, $30^{\circ} \mathrm{C}$; stirred solution. Error bar corresponds to the standard deviation of measurements performed with four different bioelectrodes.
Moreover, the regression lines for Lineweaver-Burk plots merge to the left of the $1 / I$ axis but below the $1 /$ [ASChCl] axis (results not shown) suggesting a mixed inhibition process, tending towards a non/ uncompetitive one. ${ }^{50,51}$ The corresponding inhibition constants $\left(K_{\mathrm{I}}\right.$ and $\left.K_{\mathrm{i}}\right)$ were calculated according to the following equation: ${ }^{51}$

$$
I=I_{\max }^{\prime} \times[\mathrm{S}] /\left([\mathrm{S}]+K_{\mathrm{M}}^{\prime}\right)
$$

where:

$$
\begin{gathered}
I_{\max }^{\prime}=I_{\max } /\left(1+[\operatorname{Inh}] / K_{\mathrm{I}}\right) \\
K_{\mathrm{M}}^{\prime}=K_{\mathrm{M}}^{\mathrm{app}}\left(1+[\operatorname{Inh}] / K_{\mathrm{i}}\right) /\left(1+[\operatorname{Inh}] / K_{\mathrm{I}}\right)
\end{gathered}
$$

The inhibition process for the immobilised enzyme can be described by the following kinetic scheme: ${ }^{52}$

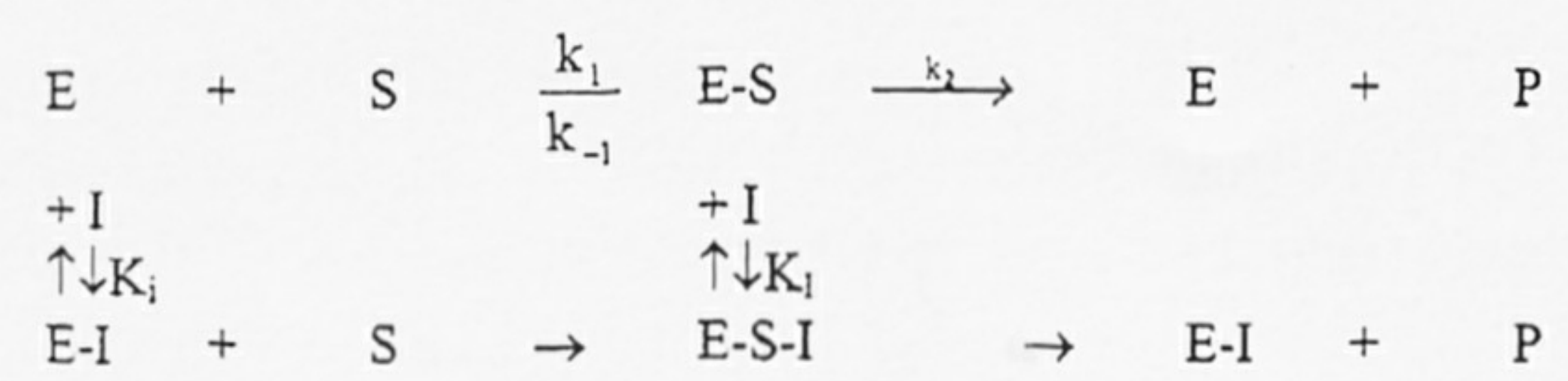

where: $\mathrm{E}$ is the immobilised enzyme, $\mathrm{S}$ is the free substrate, here $\mathrm{ASChCl}, \mathrm{P}$ is the product, here thiocholine, E-S is the enzyme-substrate complex, $\mathrm{E}-\mathrm{I}$ is the enzyme-inhibitor complex, E-S-I is the ternary complex containing enzyme-substrateinhibitor, $K_{\mathrm{I}}$, and $K_{\mathrm{i}}$ are the dissociation constants of the E-S-I complex and the E-I complex, respectively.

Thus, the secondary plots, ${ }^{51}$ i.e. $1 / I_{\max }^{\prime}$ against [Inh] and $K_{\mathrm{M}}^{\prime} / I_{\max }^{\prime}$ against [Inh], allowed estimation of the values of $K_{\mathrm{I}}$ and $K_{\mathrm{i}}$, respectively. For both tested pesticides, as expected for a non/uncompetitive inhibition, $K_{\mathrm{i}}$ was found to be higher than $K_{\mathrm{I}}$ (Table II). This denotes that the AChE inhibition might be mainly due to a reduction in the active sites density of the immobilised enzyme ${ }^{51}$ rather than to a 

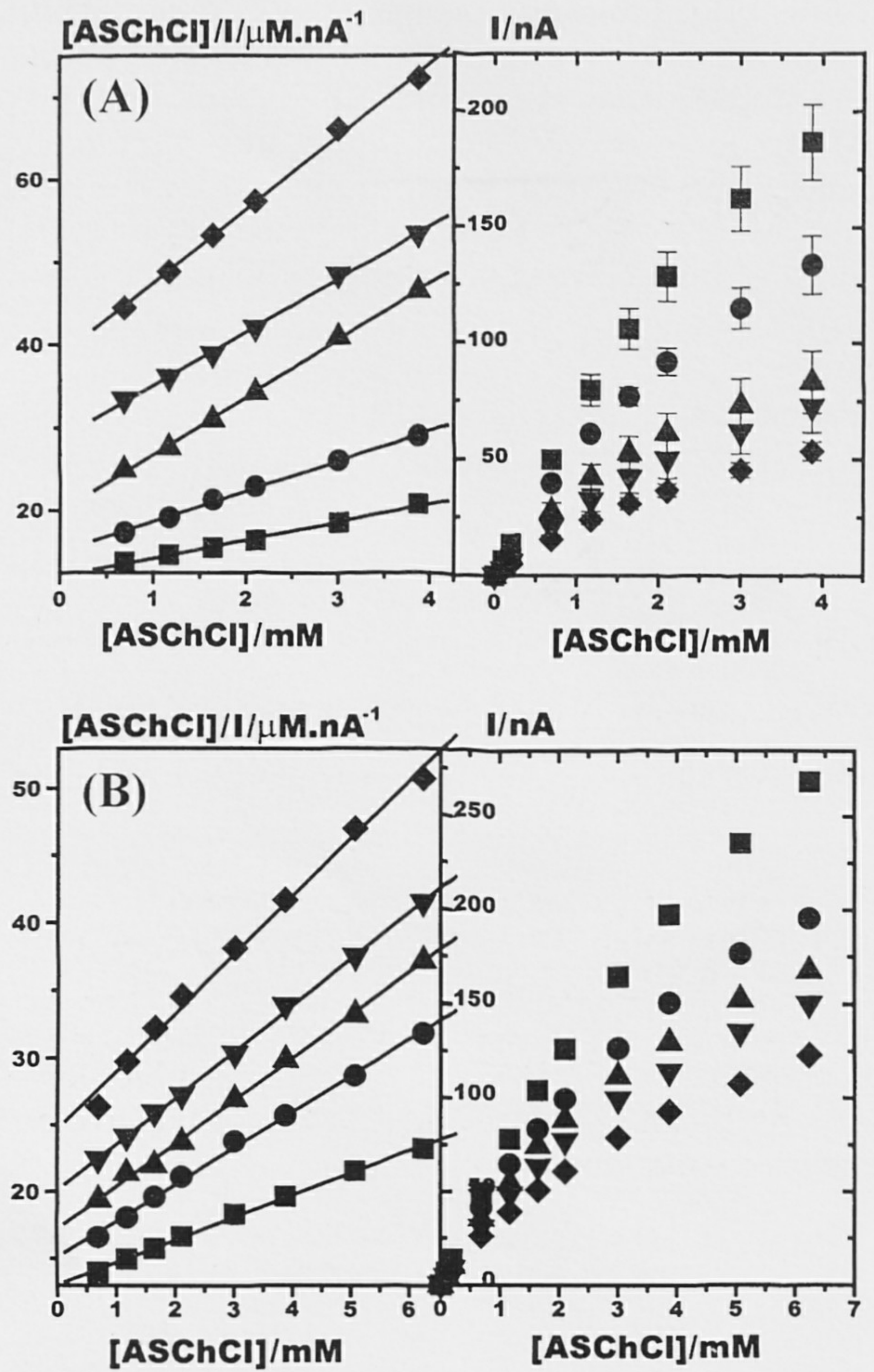

FIGURE 6 (A) Amperometric calibration curves for acetylthiocholine and the corresponding Hanes-Woolf linearisation recorded for the needle type bioelectrode before ( $\mathbf{\square}$, $n=22)$ and after its incubation in $0.5 \mu \mathrm{M}(\bullet, n=2), 2 \mu \mathrm{M}(\boldsymbol{\Delta}$, $n=4), 4 \mu \mathrm{M}(\boldsymbol{\nabla}, n=3)$ and $6 \mu \mathrm{M}(\bullet, n=4)$ paraoxon. Experimental conditions: method I; applied potential, $+0.410 \mathrm{~V}$ vs. $\mathrm{Ag} / \mathrm{AgCl}, \mathrm{KCl}_{\text {sat }}$; phosphate buffer $1 / 15 \mathrm{M}, \mathrm{pH} 8$; temperature $30^{\circ} \mathrm{C}$; stirred solution. Error bar corresponds to the standard deviation of the measurements performed with the specified number of electrodes. (B) Amperometric calibration curves for acetylthiocholine and the corresponding Hanes-Woolf linearisation recorded for the needle type bioelectrode: before (回) and after its incubation in $10 \mu \mathrm{M}(\bullet), 40 \mu \mathrm{M}(\mathbf{\Delta}), 1000 \mu \mathrm{M}(\mathbf{\nabla})$ and $1200 \mu \mathrm{M}(\bullet)$ dipterex. Experimental conditions: method I; applied potential, $+0.410 \mathrm{~V} v \mathrm{~s} . \mathrm{Ag} / \mathrm{AgCl}, \mathrm{KCl}_{\text {sat }} ;$ phosphate buffer $1 / 15 \mathrm{M}, \mathrm{pH} 8$; temperature $30^{\circ} \mathrm{C}$; stirred solution.

decreased E-S-I affinity. ${ }^{50,53}$ At the same time, this kind of inhibition mechanism offers a supplementary qualitative explanation to the experimental finding that higher enzyme loading are necessary for pesticides detection than for substrate (acetylthiocholine) detection. Furthermore, it suggests that for practical applications to pesticides detection the needle type AChE based bioelectrodes should be envisaged as disposable sensors.

Moreover, in the presence of pesticide the deviation of the biosensor response to $\mathrm{ASChCl}$
TABLE II Kinetic parameters of the bioelectrode amperometric response to $\mathrm{ASChCl}$, observed in the presence of dipterex and paraoxon as inhibitors. Experimental conditions: as in Fig. 5. See text for the significance of $K_{\mathrm{I}}$ and $K_{\mathrm{i}}$ inhibition constants

\begin{tabular}{lccc}
\hline $\begin{array}{l}\text { [Pesticide] } \\
(\mu \mathrm{M})\end{array}$ & $K_{\mathrm{M} p}^{\mathrm{app}}$ & $I_{\max }$ & $\begin{array}{c}\text { Corr. coeff. } \\
(\text { no. of data) }\end{array}$ \\
\hline
\end{tabular}

Dipterex*

\begin{tabular}{llll}
\hline 0 & $7.8 \pm 0.5$ & $599 \pm 26$ & $0.9988(8)$ \\
10 & $5.6 \pm 0.5$ & $369 \pm 20$ & $0.9986(8)$ \\
40 & $5.4 \pm 0.4$ & $312 \pm 14$ & $0.9989(8)$ \\
1000 & $5.8 \pm 0.3$ & $291 \pm 8$ & $0.9995(8)$ \\
1200 & $5.7 \pm 0.8$ & $232 \pm 20$ & $0.9963(8)$ \\
& $K_{\mathrm{I}}=2.3 \mathrm{mM}$ & & $0.9145(3)$ \\
Paraoxon $^{+}$ & $K_{\mathrm{i}}=2.6 \mathrm{mM}$ & & $0.9234(4)$ \\
\hline 0 & & & \\
\hline 0.5 & $5.5 \pm 0.9$ & $450 \pm 50$ & $0.9965(6)$ \\
2 & $4.1 \pm 0.3$ & $280 \pm 20$ & $0.9989(6)$ \\
4 & $2.9 \pm 0.2$ & $140 \pm 10$ & $0.9995(6)$ \\
6 & $4.5 \pm 0.4$ & $150 \pm 10$ & $0.9989(6)$ \\
8 & $4.3 \pm 0.4$ & $110 \pm 10$ & $0.9987(6)$ \\
10 & $3.2 \pm 0.4$ & $90 \pm 7$ & $0.9984(6)$ \\
& $5.7 \pm 1.4$ & $140 \pm 20$ & $0.9922(6)$ \\
& $K_{\mathrm{I}}=3.95 \mu \mathrm{M}$ & & $0.9495(5)$ \\
& $K_{\mathrm{i}}=5.24 \mu \mathrm{M}$ & & $0.9595(6)$ \\
\hline
\end{tabular}

$K_{\mathrm{M}}^{\mathrm{app}}$ and $I_{\max }$ confidence intervals were estimated as $S_{A / B} \times t_{N-2 ; 0.95}$ and $S_{1 / B} \times t_{N-2 ; 0.95}$, respectively; $S_{A / B}$ is the standard deviation of the ratio $A / B$; $S_{1 / B}$ is the standard deviation of $1 / B ; A$ and $B$ are the Hanes-Woolf linear regression parameters; $N$ is the number of experimental data; $t$ is the Student's variable corresponding to $(N-2)$ degrees of freedom and $95 \%$ probability. ${ }^{*} \mathrm{AChE}$ loading, $15.2 \mathrm{U} \mathrm{cm}^{-2}{ }^{+} \mathrm{AChE}$ loading $48 \mathrm{U} \mathrm{cm}^{-2}$.

from the true Michaelis-Menten kinetics was evaluated by applying the Hill Eq. (10): ${ }^{54}$

$$
\left(\Delta I / I_{0}\right) /\left(1-\Delta I / I_{0}\right)=\left(\Delta I / I_{50}\right)^{x}
$$

where: $I_{50}$ corresponds to the biosensor response at $50 \%$ inhibition and the other symbols have the already mentioned significance

The Hill coefficient $(x)$ obtained from the slope of Fig. 7 was found to be 1.3 and $1.23(R=0.999, n=8)$ for dipterex and paraoxon, respectively. Its similar values confirm that the inhibition process follows the same mechanism in spite of differences between pesticide structures. Other representations like Hughes-Klotz and Scatchard plots ${ }^{55}$ confirm the above results (results not shown). This behaviour can be due to a specific interaction between the inhibitor and the active site of the enzyme.

\section{CONCLUSIONS}

Taking advantage of a simple and enzyme activitypreserving immobilisation technique (i.e. the enzyme entrapment in a photopolymerised matrix) and a simple but efficient transducer design (i.e. a needle type Pt electrode), an AChE based amperometric bioelectrode for selective detection of organophosphorus pesticide, such dipterex and paraoxon was developed, optimised and characterised. 


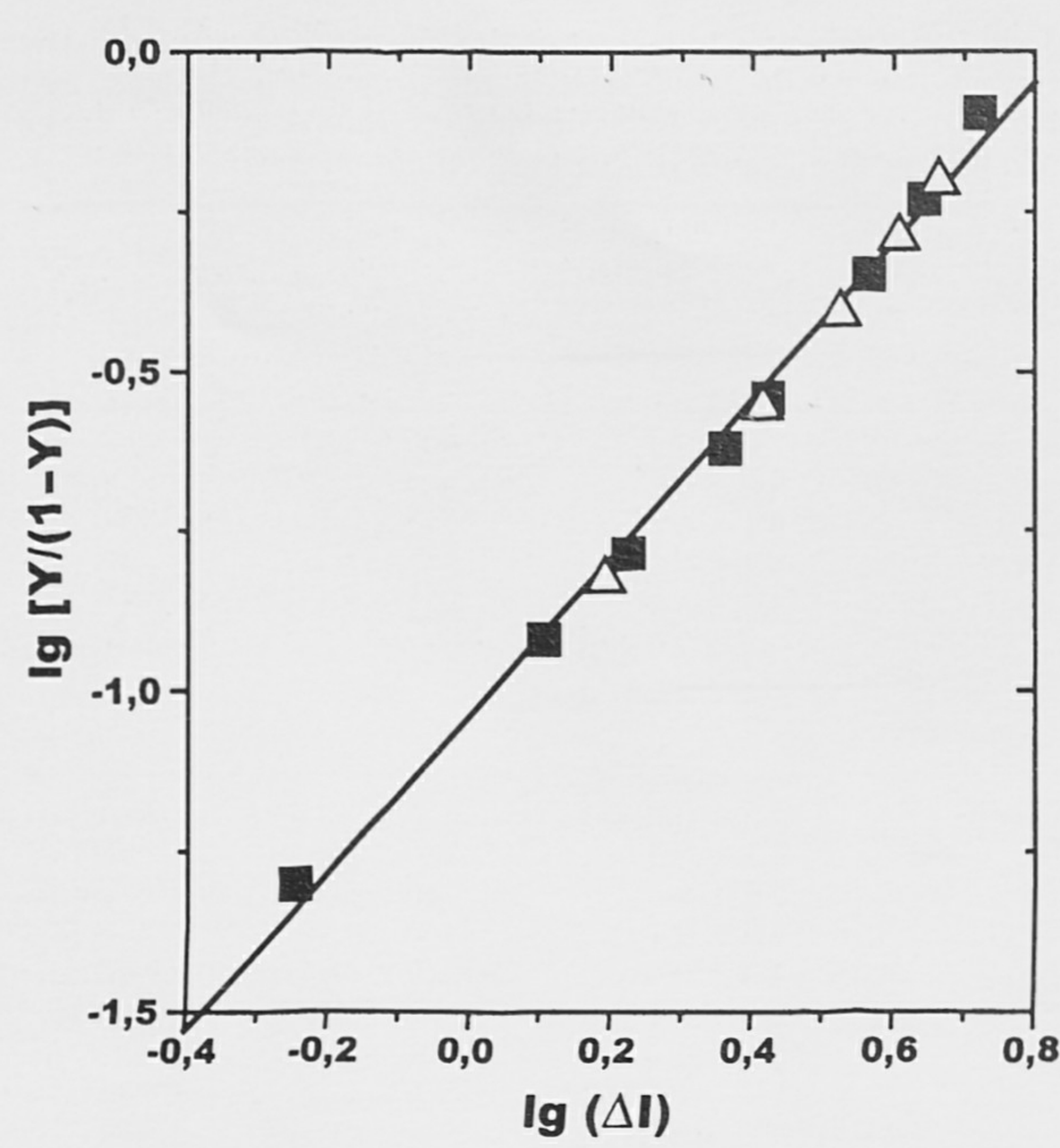

FIGURE 7 A $\log _{10}$ plot of the Hill equation for detection of paraoxon ( $\mathbf{\square})$ and dipterex $(\triangle)$ with a needle type $\mathrm{AChE} / \mathrm{Pt}$ bioelectrode. Experimental conditions: see Fig. 5; $[\mathrm{ASChCl}]=$ $1 \mathrm{mM}$ for dipterex detection and $[\mathrm{ASChCl}]=0.2 \mathrm{mM}$ for paraoxon detection.

For the first time an electrochemical investigation of thiocholine processing provides a value for its diffusion coefficient obtained using both cyclic and hydrodynamic voltammetry.

A kinetic analysis of the inhibition data of the immobilised enzyme system, allowed an identification of the pesticide-AChE inhibition as a mixed non/uncompetitive one for both paraoxon and dipterex, as well as estimation of the kinetic parameters for the inhibition process corresponding to the two possible enzyme-inhibitor binding equilibrium. The response deviation of the needle type AChE/Pt bioelectrode from classical Michaelis -Menten kinetic was evaluated by the Hill coefficient calculated from different types of representations (Hill, Hughes-Klotz and Scatchard). Despite the difference in pesticide structure the Hill coefficient has the same value.

The intrinsic advantages of the developed needle type AChE based amperometric bioelectrode are easy production, low cost, simple handling and good analytical characteristics (high sensitivity and response rate, extended linear range and low detection limit) which recommend it as a promising sensor in a warning device for accidental river pollution.

\section{Acknowledgements}

This work was made possible by grants from the Ministry of Research and Technology and the
Ministry of Education (Romania). G.L.T. is grateful to the French Government for the financial support of her studies. Also, she would like to thank Prof. J.-L. Marty for valuable suggestions and discussions concerning the AChE bioelectrode and for the kind gift of PVA-SbQ. I.C.P. acknowledges financial support from a Swedish Institute scholarship.

\section{References}

[1] Alfonta, L., Katz, E. and Willner, I. (2000), Anal. Chem. 72, 927.

[2] Li, Y.-G., Zhou, Y.-X., Feng, J.-L., Jiang, Z.-H. and Ma, L.-R. (1999), Anal. Chim. Acta 382, 277.

[3] Campanella, L., de Luca, S., Sammartino, M.P. and Tomassetti, M. (1999), Anal. Chim. Acta 385, 59.

[4] Marty, J.-L., Mionetto, N., Noguer, T., Ortega, F. and Roux, C. (1993), Biosens. Bioelectron. 8, 273.

[5] Mionetto, N., Marty, J.-L. and Karube, I. (1994), Biosens. Bioelectron. 9, 463.

[6] Lenigh, R., Lam, E., Lai, A., Wang, H., Han, Y., Carlier, P. and Renneberg, R. (2000), Biosens. Bioelectron. 15, 541.

[7] Kumaran, S. and Morita, M. (1995), Talanta 42, 649.

[8] Ivanov, A.N., Evtugyn, G.A., Gyurcsanyi, R.E., Toth, K. and Budnikov, H.C. (2000), Anal. Chim. Acta 404, 55.

[9] Arkhypova, V.N., Dzyadevych, S.V., Soldatkin, A.P., El'skaya, A.V., Jaffrezic-Renault, N., Jaffrezic, H. and Martelet, C. (2001), Talanta 55, 919.

[10] Gyurcsanyi, R.E., Vagfoldi, Z., Toth, K. and Nagy, G. (1999), Electroanalysis 11, 712 .

[11] Martorell, D., Céspedes, F., Martinez-Fabregas, E. and Alegret, S. (1997), Anal. Chim. Acta 337, 305.

[12] La Rosa, C., Pariente, F., Hernandez, L. and Lorenzo, E. (1995), Anal. Chim. Acta 308, 129.

[13] Skladal, P. and Mascini, M. (1992), Biosens. Bioelectron. 7, 335.

[14] Skladal, P. (1992), Anal. Chim. Acta 269, 281.

[15] Skladal, P. (1993), Biosens. Bioelectron. 32, 145.

[16] Skladal, P., Pavlik, M. and Fiala, M. (1994), Anal. Lett. 27, 29.

[17] Bier, F.F. and Schmid, R.D. (1994), Biosens. Bioelectron. 9, 125.

[18] Brecht, A., Piehler, J., Lang, G. and Gauglitz, G. (1995), Anal. Chim. Acta 311, 289.

[19] Hock, B., Dankwardt, A., Kramer, K. and Marx, A. (1995), Anal. Chim. Acta 311, 393.

[20] Halbert, M.K. and Baldwin, R.P. (1985), Anal. Chem. 57, 591.

[21] Chen, Q., Kobayashi, Y., Takeshita, H., Hoshi, T. and Anzai, J.-I. (1998), Electroanalysis 10, 94.

[22] Navera, E.N., Suzuki, M., Yokoyama, K., Tamiya, E., Takeuchi, T. and Karube, I. (1993), Anal. Chim. Acta 281, 673.

[23] Lopez Ruiz, B., Dempsey, E., Hua, C., Smyth, N. and Wang, J. (1993), Anal. Chim. Acta 173, 425.

[24] Espinosa, M., Atanasov, P. and Wilkins, E. (1999), Electroanalysis 11, 1055.

[25] Jeanty, G., Ghommidh, Ch. and Marty, J.-L. (2001), Anal. Chim. Acta 436, 119.

[26] Wilkins, E., Carter, M., Voss, J. and Ivnitski, D. (2000), Electrochem. Commun. 2, 786.

[27] Jaffrezic-Renault, N. (2001), Sensors 1, 60.

[28] Albareda-Sirvent, M., Merkoci, A. and Alegret, S. (2001), Sensors Actuators B 79, 48.

[29] Zhang, S., Zhao, H. and John, R. (2001), Biosens. Bioelectron. 16, 1119.

[30] Zhang, S., Zhao, H. and John, R. (2001), Electroanalysis 13, 1528.

[31] Montesinos, T., Perz Munguia, S., Valdez, F. and Marty, J.-L. (2001), Anal. Chim. Acta 431, 231.

[32] Mionetto, N., (1993). PhD Thesis, Université de Perpignan.

[33] Allietta-Labat, N. and Thévenot, D.R. (1998), Biosens. Bioelectron. 13, 19.

[34] Turdean, G., Peter, I., Popescu, I.C. and Oniciu, L. (1997), Rev. Roum. Chim. 42, 879.

[35] Muresan, L., Nicoara, A., Varvara, S. and Maurin, G. (1999), J. Appl. Electrochem. 29, 719.

[36] Bard, A.J., Faulkner, L.R., eds, (1980) Electrochemical Methods. Fundamentals and Applications (Wiley, New York), p 222. 
[37] Brett, C.M.A. and Oliveira Brett, A.-M. (1993) Electrochemistry. Principles, Methods and Applications (Oxford University Press, New York), p 174.

[38] Hart, J.P. and Hartley, C. (1994), Analyst 119, 259.

[39] Gruss, R., Scheller, F., Shao, M.J. and Liu, C.C. (1989), Anal. Lett. 22, 1159.

[40] Evtugyn, G.A., Ivanov, A.N., Gogol, E.V., Marty, J.-L. and Budnikov, H.C. (1999), Anal. Chim. Acta 385, 13.

[41] Turdean, G.L., Mosneag, C.S. and Popescu, I.C. (2000), ACHModels Chem. 137, 519.

[42] Pandey, P.C., Upadhyay, S., Pathak, H.C. and Pandey, C.M.D. (2000), Sensors Actuators B 62, 106.

[43] Pleskov, Yu.V. and Filinovskii, V.Yu. (1976) The Rotating Disc Electrode (Consultants Bureau, New York), pp 81-109.

[44] d'Urso, E.M. and Coulet, P.R. (1993), Anal. Chim. Acta 281, 535.

[45] Bernabei, M., Cremisini, C., Mascini, M. and Palleschi, G. (1991), Anal. Lett. 24, 1317.
[46] Palchetti, I., Cagnini, A., Del Carlo, M., Coppi, C., Mascini, M. and Turner, A.P.F. (1997), Anal. Chim. Acta 337, 315.

[47] Andreas, R.T. and Narayanaswamy, R. (1997), Talanta 44, 1335.

[48] Hartley, I.C. and Hart, J.P. (1994), Anal. Proc. Anal. Commun. 31,333 .

[49] Stoytcheva, M. (1994), Anal. Lett. 27, 3065.

[50] Berman, H.A. and Leonard, K. (1990), Biochemistry 29, 10640.

[51] Trevor Palmer, B.A. (1987) Understanding Enzymes (Ellis Horwood Limited, Chichester, West Sussex), pp 142-160.

[52] Venkateswara Prasad, G., Indira, K and Rajendra, W. (1987), Bull. Environ. Contam. Toxicol. 38, 139.

[53] Tian, W.-X. and Tsou, C.-L. (1982), Biochemistry 21, 1028.

[54] Adeyoju, O., Iwuoha, E.I. and Smyth, M.R. (1994), Anal. Lett. 27, 2017.

[55] Chang, R. (1990) Physical Chemistry with Applications to Biological Systems (MacMillan Publishing Co, New York), pp 248-251. 